Guest Editorial, part of a Special Feature on Community-based Management of Environmental Challenges in Latin America and the Caribbean

\title{
Community-based management of environmental challenges in Latin America and the Caribbean
}

\author{
Maria del Mar Delgado-Serrano ${ }^{1}, \underline{\text { Jayalaxshmi Mistry }}^{2}$, Bettina Matzdorf $^{3}$ and Gregoire Leclerc $^{4,5}$
}

\begin{abstract}
This Special Feature gathers the results of five research projects funded by the 7th Research Framework Program of the European Union and aims to identify successful cases of community-based management of environmental challenges in Latin America. The funding scheme, Research for the benefit of Civil Society Organizations, fostered innovative research approaches between civil society and research organizations. More than 20 field sites have been explored, and issues such as trade-offs between conservation and development, scientific versus local knowledge, social learning, ecosystem services, community owned solutions, scaling-up and scalingout strategies, the influence of context and actors in effective environmental management and governance, and the conflicts of interests around natural resources have been addressed. Based on our experiences as project coordinators, in this editorial we reflect on some of the important lessons gained for research praxis and impact, focusing on knowledge of governance models and their scaling-out and scaling-up, and on methods and tools to enable action research at the science-civil society interface. The results highlight the richness of community-based management experiences that exist in Latin America and the diversity of approaches to encourage the sustainable community-based management of environmental challenges.
\end{abstract}

Key Words: CIVINET; COBRA; COMBIOSERVE; COMET-LA; ECOADAPT; governance models; local and scientific knowledge; science-society

\section{INTRODUCTION}

Global environmental changes have never been as rapid, large, complex, and potentially catastrophic as they are now (Flannery 2007). Current economic development models, struggling to incorporate environmental externalities, are exerting increasing pressures on natural resources at local and global scales. Approaches for addressing challenges such as climate change, food security, land erosion, biodiversity loss, and water security need to recognize that natural resources are part of complex and highly dynamic social-ecological systems (Berkes and Folke 1998). And critically, modes of governance and management need to move away from oversimplifying relations between society and nature and one-size-fits-all recommendations that to date have produced mismanagement and failures, and explore alternative visions of development.

The effects of global environmental change are most keenly felt by local people, especially communities that traditionally base their livelihoods in natural resources. There has been a growing recognition that communities closely connected to natural resources are likely to foster sustainable use based on their intimate knowledge and long-term local experience (Dietz et al. 2003, Cox et al. 2010, Mistry and Berardi 2016). Such rural communities have historically developed different livelihood strategies and customary practices and institutions to reduce vulnerability to external threats while enhancing social-ecological resilience (Ostrom 1990, Kellert et al. 2000, Colding et al. 2003, Berkes 2004). At the same time, failures in top-down governmentbased conservation strategies have led to a move to devolve natural resource management decisions to the local level (Brosius et al. 1998), which creates new political opportunities for local communities to regain control over resources and address issues of environmental sustainability and social justice (Western and Wright 1994, Hayes 2007).

Community-based natural resources management (CBNRM) initiatives have attracted considerable national and international interest over the last few decades, and different government and donor agencies have provided significant financial support (Shackleton et al. 2010). There is evidence that these initiatives can promote long-endurance indigenous management systems, effective land and sea common pool resources management, and the devolution and recognition of existing community rights within sustainable CBNRM strategies (e.g., Ostrom 1990, Klooster 2000, Kamran and Shivakoti 2009). However, there have also been challenges of elite capture of benefits (Fabricius and Collins 2007), failures in governance and leadership (Bohensky and Lynam 2005), withdrawal of technical and financial support (Balint and Mashinya 2006), difficulties in replicating and scalingup approaches (White et al. 2002), and inequitable distribution of benefits (Suich 2013). It is clear that understanding the context and the history, as well as the local and wider institutional dynamics that have shaped CBNRM (Kinzig et al. 2013), and the community indicators of success and well-being (Znajda 2014), is critical for assessing the extent to which these CBNRM initiatives are able to deal with environmental challenges and support livelihoods.

Latin America and the Caribbean (LAC) region is one of the most water-rich areas of the world, comprising approximately onequarter of the world's tropical forests (FAO 2015) and supporting a rich biological diversity, which accounts for $60-70 \%$ of all known life on Earth (UNEP 2016). The region's exceptional diversity of ecosystems includes 12 of the 14 world biomes and

\footnotetext{
${ }^{1}$ Department of Agriculture Economics, Sociology and Policy, Universidad de Córdoba, Spain, ${ }^{2}$ Department of Geography, Royal Holloway University of London, UK, ${ }^{3}$ Leibniz Centre for Agricultural Landscape Research (ZALF), ${ }^{4}$ CIRAD, UPR GREEN, Montpellier, France, ${ }^{5}$ CATIE, Climate Change and Watersheds Program, Turrialba, Costa Rica
} 
191 of the 867 unique eco-regions of the world (Olson et al. 2001). Furthermore, it encompasses six of the 17 megadiverse countries of the world, according to the UNEP-WCMC (Mittermeier et al. 1997). The state of the LAC environment is maintained by the numerous indigenous and local communities that inhabit the diverse ecosystems. There is increasing evidence that indigenous lands protect the natural environment through reduced rates of deforestation and habitat conversion, and lower greenhouse gas emissions compared to surrounding areas (e.g., Nolte et al. 2013, Vergara-Asenjo and Potvin 2014, Walker et al. 2015). Ecosystems are protected within indigenous lands not because they are being "managed" in a direct and active way, but as the indirect outcome of a healthy community within its environment; i.e., sustainable management results from sophisticated practices that maintain social and ecological integrity. The extensive knowledge of indigenous and local communities, and the practices they implement to manage their land, could offer novel and effective solutions to current and upcoming challenges in the region.

These socio-economic and environmental challenges include increasing pressures from population growth, urbanization, economic development, and growing inequity and poverty rates. LAC's economy and social development depend largely on natural resources, but this is currently taking place at the expense of the natural environment. For example, LAC loses approximately 2.18 million hectares of its forests annually (FAO 2015). Additionally, climate change is expected to highly impact the national economies of the region and the well-being of communities (IPCC 2014) while exacerbating exposure to various types of natural hazards such as earthquakes, volcanic eruptions, and tsunamis, and storms, hurricanes, floods, and droughts associated with the El Niño Southern Oscillation (UNECLAC 2014). Thus, the future of the region's economies, as well as the ability of LAC countries to fight poverty and reverse inequality, depends heavily on the region's environmental resources and the ability to find effective governance and management models (UNEP 2016). Ensuring the participation of indigenous and local communities in environmental governance not only makes solutions more sound, it respects local cultures, promotes social justice, and establishes self-determination as a key principle of engagement.

It is within this context that in 2011, the 7th Research Framework Program of the European Union launched a call to identify evidence of successful community-based management of environmental challenges in Latin America. The call objectives were to "identify and analyse locally owned and developed solutions put in place to prevent and resolve tensions arising from a necessary new repartition and use of natural resources, including ecosystem services, due to environmental and climate changes." The topic was funded under a novel funding scheme: Research for the benefit of Civil Society Organisations (CSOs), and as such, required the creation of partnerships between civil society and research organizations to foster innovative research approaches.

This Special Feature brings together experiences from the five projects funded by the call. COMET-LA (http://www.comet-la. eu) was based on the creation of a learning arena to share local and scientific knowledge and to analyze sustainable governance models for different environmental challenges, such as the management of forest, water, biodiversity, and marine and coastal areas. COBRA (www.projectcobra.org) concentrated on identifying, promoting, and sharing community owned solutions for environmental management using innovative visual methodologies. CiVi.net (http://www.civinet.eu) analyzed, transferred, and disseminated successful and sustainable community-based solutions linked to ecosystem service management. The role of CSOs within the successful governance models was at the core of the research. COMBIOSERVE (http:// combioserve.animalared.org) monitored the current status of natural resources in community conservation areas by analyzing the related governance models and developing scenarios toward resilient adaptive management. Finally, EcoAdapt (http://www. ecoadapt.eu), through action-research led by CSOs, contributed to increasing the adaptive capacity of local partners to address water security in a context of climate change in three "Model Forests."

Within these five projects, local actions in different socialecological contexts were analyzed in several countries and more than 20 field sites. Issues such as trade-offs between conservation and development, scientific versus local knowledge, social learning, ecosystem services, community owned solutions, scaling-up and scaling-out strategies, the influence of context and actors in effective environmental management and governance, and the conflicts of interests around natural resources were analyzed in the different case studies. A range of locally adapted methods and approaches were used to engage local communities in research, to foster community empowerment and capacity building, and to link local and scientific knowledge. Using our experiences as coordinators of the projects, in this editorial we reflect on some of the important lessons gained for research praxis and impact. More specifically, we highlight areas in which there is improved knowledge of governance models and their scalingout and scaling-up through policy, and approaches, methods, and tools that enable action research at the science-civil society interface.

\section{MODELS OF GOVERNANCE}

There is growing consensus that effective management and governance of environmental challenges requires policies and actions that are compatible with the realities and perspectives of local communities that have the most direct contact with the environment yet have the most to lose from environmental degradation (e.g., Dressler et al. 2010, Scales 2012). Critical to supporting and strengthening local governance models is an indepth understanding of how they function and the way they maintain and can enhance social-ecological sustainability.

COMET-LA used Ostrom's social-ecological system (SES) framework to investigate how forest, biodiversity, freshwater, and marine systems were being managed by indigenous communities in the Sierra de Oaxaca (Mexico), Afrocolombian communities in Alto y Medio Dagua and Calima (Colombia), and artisanal fishers in Estuary of Bahia Blanca (Argentina) (Escalante et al. 2012, Farah et al. 2012, London et al. 2012). The process allowed the communities to analyze the main threats they faced and to have a shared understanding of how the governance system affects trade-offs between conservation and development (Delgado- 
Serrano et al. 2016). For example, in the Mexican case, conservation is privileged, but it comes with the cost of a lack of opportunities and youth migration (Delgado-Serrano et al. 2015b). Argentine fishers have higher development standards but face greater individualistic behavior, which undermines collective action. For the Colombian communities, their natural capital does not provide livelihood options outside natural resource extraction, and illegal actors (miners and coca traders) create additional pressures on the land. Analysis of local perceptions showed that within these SESs, the use of ancestral knowledge (Colombia), the history of land use (Mexico), and the history of the artisanal fishery (Argentina) were all common challenges to community-based natural resource management (DelgadoSerrano et al. 2015a).

COBRA's community owned solutions approach suggests that environmental management and governance requires a suite of strategies that local communities themselves have identified and assessed (Mistry et al. 2016). In the case of indigenous communities of the North Rupununi, Guyana, this includes traditional ecological knowledge linked to local cultural values, the transmission of this knowledge throughout the community but especially to young people, strong local CSOs and community leaders, a collective spirit with a degree of personal sacrifice, support when needed from external bodies/organizations, and adoption/use of new communication technologies. Crucially, the System Viability framework used in the project enabled the identification of best practices for governance that have synergistic effects and are mutually reinforcing; i.e., they do not focus on promoting one aspect of a community while undermining another (Berardi et al. 2015). For example, community self-help as a governance strategy is used in traditional farming and fishing, as part of ecotourism, and in cultural transmission activities.

While it is important to identify community owned strategies for supporting livelihoods and protecting biodiversity, exploring what motivates local people to be engaged in practical institutional arrangements helps to understand how they respond to pressures and incentives. COMBIOSERVE found that the drivers and motivations for community-based conservation of indigenous communities in Brazil, Bolivia, and Mexico differed considerably as a result of distinct external and internal (intracommunity) processes that determine social-ecological change (Ruiz-Mallén et al. 2015a). For example, in the Calakmul community in Mexico, a key driver of conservation is a statedriven policy for direct forest conservation through a payment for ecosystem services (PES) program, which involves a 5-year payment renewable and collective contract. However, this has increased livelihood dependence on external funding sources and exacerbated existing inequalities between landholders who directly receive these payments and landless community members who do not have access to PES. It also seems to be changing the local rationality of management toward opportunistic behaviors that might lead to conservation trade-offs in the near future. For instance, Calakmul landholders might stop conserving forested areas in their commons as they traditionally did if they do not get paid in the future (Ruiz-Mallén et al. 2015b). In the Brazilian and Bolivian case studies, COMBIOSERVE identified broader national struggles for indigenous rights as a key motivation for conservation. For example, the establishment of the Coroa Vermelha Indigenous Territory in 1997 allowed the Pataxó to gain formal usufruct rights over such territory lands, and they in turn set aside an area of 827 ha to preserve the forest against urbanization pressures. And while the arrival of tourists to the region and the need to gain further social recognition as an indigenous group helped consolidate the locally protected area over time, the increase in tourism represents a challenge for conservation if, over time, it contributes to displacing culturally rooted conservation principles without a balance between ethnotourism initiatives and sustainable, economically profitable resource management (Ruiz-Mallén et al. 2015a).

Indeed, recognizing how communities exist within the multiple, networked, and dynamic interrelationships between stakeholders operating at different scales is important to ensure that coherent decision-making on environmental management is taking place. EcoAdapt worked with "Model Forests" (multistakeholder territorial dialogue and mediation platforms to enable sustainable forest management) to improve water security in marginal territories in Argentina, Bolivia, and Chile that were neglected by the state and subject to high rates of poverty (Fallot and Le Coq 2014, Devisscher et al. 2016). Despite state-led processes and sectorial arenas that allowed community participation, Model Forests and external projects (e.g., development or research) provide ad hoc, legitimate, and relatively accessible spaces around cross-sectorial issues. However, this adds to the agendas of local community participants, which creates fatigue and frustration because of the difficulty of making decisions in mixed arenas that are subject to cognitive mismatch and power plays. The success of Model Forests depends on the attractiveness of the mobilizing issue (water security in the case of EcoAdapt), clarity of the objectives, transparency in management, leadership, mediation skills, and perseverance of the actors involved in "muddling through"; i.e., learning and adapting to difficult contexts and structural changes (Devisscher et al. 2016, Vignola et al., unpublished manuscript). When those conditions are met, key actors may take advantage of inevitable problems (e.g., due to political mayhem) to tighten existing alliances, attract new powerful actors at different levels, and rethink their intervention for improved impact.

Civil Society Organizations are one of these key actors for sustaining local governance. Using case studies from Brazil and Costa Rica, CiVi.net showed how community-led governance processes are reinforced by committed CSO actors who function as innovators and intermediaries between other actors (Sattler et al. 2015, Sattler and Schröter 2015). For example, in southern Brazil's Encostas da Serra Geral region, a group of university students and academics initiated and fostered the implementation of the sustainable agricultural land management system called "Voisin." As intermediary actors, they combined scientific knowledge with social skills and high intrinsic motivation, which promoted trust and enabled the innovation to be accepted by the farmers. In Costa Rica, a CSO acts as an intermediary in a PES scheme on "Blue Carbon" to support the restoration of mangroves in the area. The CSO has different organizational levels on the national and local scale, which allows it to establish both formal networks for connecting the international to the local level and informal networks for creating trustworthy relationships 
among the actors. But the CSO is not only a multilevel bridge in the PES scheme - it is also permanently engaged in the process, thus helping to guarantee the balance of power and the interests of local development, knowledge integration, and transparency.

While actors such as CSOs can play focal roles in making local governance work for local communities, solutions for good governance can also come from other communities facing similar challenges. In COBRA, community peer-to-peer knowledge exchange proved to be a successful way of instilling positive change in the indigenous communities of the Guiana Shield. Horizontal knowledge exchange creates a climate of trust and breaks hierarchies, making community members significantly more receptive to solutions emerging from, and communicated by, other indigenous peoples (Tschirhart et al. 2016). The transfer of "success stories" was a motivating force for galvanizing communities to make changes in their own community. These success stories inspired communities to reflect on their own challenges and adapt and implement solutions from other indigenous communities. It engendered motivation to act, ownership over the process, organizational skills in implementation, and indigenous pride in local solutions. Similarly, community peer-to-peer knowledge exchange helped women in COMET-LA's Mexican case study claim a voice in community decision-making after interacting with female leaders in the Colombian community and learning the role they played in local governance. In CiVi.net, local fishers from Costa Rica who were participating in a PES scheme on mangrove protection exchanged knowledge with two other regions, which stimulated those communities to establish new projects on oyster farming and local environmental tourism.

\section{ENABLING ACTION RESEARCH AT THE SCIENCE- CIVIL SOCIETY INTERFACE}

Participation in community-based management has too often been synonymous with "consultation" or "listening to" local communities. Our research shows that when local communities are more involved in the research-i.e., in the production of knowledge about their own context-specific realities, and implementation process - they are empowered, and it can bring about effective and long-lasting impacts. A greater focus on the process, ethics, outcomes, and impacts of participation is needed, rather than on outputs and end products.

This means applying a critical approach (as in Foucault 2007) right from the start, acknowledging that all knowledge should have equal value, and that researchers and local communities can benefit from adopting a knowledge culture based on joint learning. This engenders scientists from various disciplines to tailor their research to the context and worldviews of their counterparts, while local actors learn about different ways to frame the problem and contribute to possible solutions that scientists can help support or design (Prins et al. 2015). In EcoAdapt, researchers and CSOs worked together in framing the problem, adapting and validating the methodologies, collecting and analyzing the data, and writing technical reports and scientific articles (Desvisscher et al. 2016). This helped the CSOs gain a broader vision/reach on the issue of water security, adopt a more systemic approach, master modeling and evaluation tools, and become better organized and confident in what to expect from scientists in local development projects. At the start of the project, poor understanding of the research activities by CSOs (and limited communication from the scientists), and a lack of appreciation by the scientists for the daily constraints that CSOs face led to many unmet expectations and generated some distress. However, over time and through their proximity to local action, the scientists' role expanded as they became more trusted (e.g., through mediation, facilitation, unlocking bottlenecks), which helped improve their grasp on the context, adapt their methods, and deepen their analyses.

Similarly, in COMET-LA, local and scientific knowledge were shared and different tools were adapted to be used in and by the communities. Locally adapted methodological frameworks for social-ecological system characterization (Delgado-Serrano and Ramos 2015), prospective structural analysis (Delgado-Serrano et al. 2016), and scenario building (Waylen et al. 2015) helped local communities and researchers have a better understanding of the current situation and best practices in the management of livelihood conflicts derived from competing uses and users of natural resources; e.g., Argentine stakeholders understood the need to elaborate integrated management plans for tourism and for coastal and fisheries management (Delgado-Serrano et al. 2015a). Results from COMBIOSERVE show that taking a coenquiry research approach can be empowering for both CSOs and communities by generating a sense of possibility and power among local communities regarding natural resource decisionmaking. Furthermore, local communities in Mexico and Bolivia are now less likely to accept the nonparticipatory approaches they were used to when engaged in previous research projects (Caruso et al. 2016).

Using methodological approaches that help engage local communities in participatory processes while giving researchers greater insight into local worldviews is vital. There also needs to be awareness that written forms of communication only really serve groups of people who can access the written form; e.g., more educated, wealthier people. COBRA research shows that visual and oral communication is not only more accessible to local communities, it gives voice and ownership over their own forms of representation. Visual methods of participatory video (PV) and participatory photography (PP) help bring together different people's views and ideas on particular issues, and help communicate them in an easy and clear way (Bignante 2010, Mistry and Berardi 2012). In COBRA, PV and PP not only generated an incredibly rich and varied data set, the methods also stimulated creativity by allowing people to see things from a different perspective, which fostered discussion and enabled both horizontal (community to community) and vertical (community to regional/national/international decision-makers) interaction (Berardi et al. 2013, Mistry et al. 2014a). Through a PV process with local stakeholders in Ilha do Cardoso in São Paulo State, Brazil, CiVi.net researchers had the chance to identify community problems they would have overlooked by using only indepth interviews, while community members who watched the final film on the last day of the field visit got new insights on their own community life.

Participatory scenario planning used in COMBIOSERVE, COMET-LA, and COBRA, facilitated through visual methods 
such as storyboards, helped local communities and researchers build a common understanding of current challenges, and fostered learning about future planning of social-ecological systems (Mistry et al. 2014b, Ruiz-Mallén et al. 2015b, Waylen et al. 2015). Although participatory prospective (backed by models) was planned at the EcoAdapt design stage, it was replaced by a simple planning process for a mobilizing, pressing issue (water security) with joint implementation of quick-start pilot development projects to build trust, engagement, and capacity to enable the conditions for more complex planning and modeling (Vignola et al. 2014). Participatory modeling used in EcoAdapt to explore the pressing issue of water security developed visual representations of the social-ecological system that greatly helped participants grasp its complexity, as well as the relations between different sectors (Leclerc 2014, Fallot and Le Coq 2015). In CiVi. net, a new tool for participatory social network analysis, called Net-Map (Schiffer and Hauck 2010), allowed qualitative data based on interviews about establishing environmental management schemes to be jointly analyzed and visualized in the form of network maps by both researchers and participants. This joint elaboration of the network map with immediate visible results built a common understanding of the problem while granting participants a chance to reflect on the network in real time.

Thus, action research at the science-civil society interface entails researchers to be a participating observer/actor of local dynamics, aware of the meaning of things for the local actors as well as their aims and obligations. This leads to questioning mainstream research policy and practice, which often requires distance from the field to meet academic standards and agendas, while in reality, doing "research in society" requires close interaction in, for example, socio-technical (hybrid) forums (Callon et al. 2001). This demands more flexible funding schemes that allow for face-toface meetings between researchers and communities from the time of proposal drafting, and research and administrative processes that are more adaptable to local dynamics and the capacities of all participants (Caruso et al. 2016). This stresses the importance of involving local researchers (who may not be scientists themselves) in the research process. Indeed, a key aspect of COBRA was that all research at the local level, including the PV and PP, was carried out by community researchers - indigenous people who came from the communities where research was taking place (Mistry et al. 2015). Similarly, CSO staff asked to be deeply involved in EcoAdapt's research (with as little participation of foreign students as possible), with many exchanges and meetings with scientists for methodological design, training for social science research, data collection, and analysis. COMET-LA's Colombian team trained 25 coresearchers, including community leaders, in the use of different tools and methods that now can be applied and adapted to the community needs. In that way, the research had more ownership by the communities and the community researchers were empowered to take the lead in making change in their communities. Crucially, the information emerging out of the process was a genuine representation of community needs and aspirations, rather than a reinterpretation of them by a noncommunity member, who may have adapted the information in order to suit their particular interests and worldview.

\section{MOVING FORWARD}

The outcomes of the five projects have highlighted the richness of community-based management experiences that exist in Latin America and the diversity of approaches to encourage sustainable management of natural resources to address different environmental challenges. We have analyzed the effects of global changes and socio-environmental challenges at the community level and delivered knowledge of local-global interactions, rational use of resources, and governance models, with a special focus on the vulnerabilities of local communities and how to enhance resilience for the future.

The involvement of communities and CSOs in the research has opened new avenues to empowerment and capacity building, and has allowed us to test different methods of collaboration, citizenscience, and colearning. The results can readily be scaled-up and scaled-out and can be useful for academics and practitioners, but also for other communities in the region. However, the nature of (short-term) funding cycles meant that the projects ended just when trust between partners was growing and mutual recognition processes could have generated better results for both communities and researchers.

To analyze the research advances presented in this Special Feature, it is useful to make the distinction between "science,"-i.e., the objective, undisputable scientific fact - and "research," which is a process that is more uncertain, risky, and "subobjective," and where the scientific fact is what is being constructed; i.e., science in the making (Latour 2001). In all five projects, we observed a change in the scientific paradigm, with less emphasis on the former and more on the latter; i.e., on a scientific practice embedded in a dynamic political and societal context. Indeed, this emerging position of science was highlighted during the 7 th Annual Conference of the Ecosystem Services Partnership in September 2014 in San Jose, Costa Rica. In the press release issued on 12 September 2014, a group of researchers from the five projects who composed this Special Feature proposed what they believe are the 10 crucial steps to improve the practice of researchers working at the science-society interface (Fig. 1).

A research practice based on a joint process of enquiry requires legitimizing partial as well as qualitative evidence, a recognition that research is not only the domain of scientists but also of local people, and an acknowledgement that solutions to environmental challenges emerging from local communities have a greater chance of ownership and success. There needs to be greater efforts by researchers and CSOs on communicating this; on the one hand, to policy-makers who develop funding and governance models, and on the other hand, to local communities, many of whom have suffered a history of environmental management impositions, which has led to a culture of dependency and apathy. With the current political and economic crises in many LAC countries and the relevance of natural resources in the region's economy, working in more effective and participatory ways with local communities to ensure environmental sustainability in this biodiverse region becomes ever more urgent. 
Fig. 1. Crucial steps to improve the science-society interface.

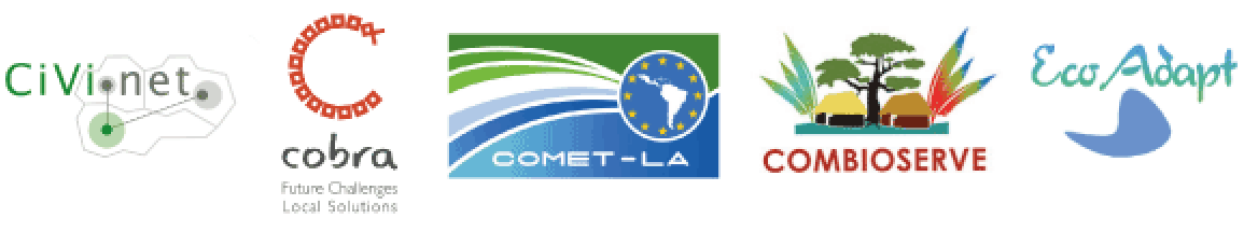

\section{The new expert - a survival guide}

\section{Post-normality in practice}

San José, Costa Rica. A group of researchers of the five projects funded by the European Union to study and disseminate community management of ecosystem services in Latin America, pose what they believe are the 10 crucial steps to improve the practice of researchers working in these areas. This is coming from a collaborative learning process during the implementation of CiVi.net, Cobra, COMET-LA, EcoAdapt and COMBIOSERVE projects.

\section{Become the new expert in 10 steps:}

1. Be friends with an artist "Work with your local art school" (Tim Reutemann, CiVi.net)

2. Become a polyglot

3. Be experimental "Don't be afraid of failure!" (Elisa Bignanti, COBRA)

4. Network everything

5. Do not fear the hard numbers

6. Get your hands dirty

7. Put yourself into the equation

8. Break the rules - but know why

9. Embrace power

10. Use all your brains
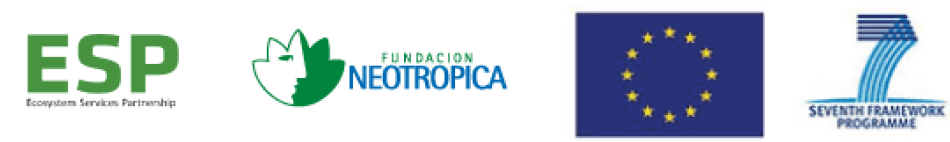

$7^{T H}$ Annual Ecosystem Services Partnership Conference 2014 - Local Action for the Common Good

\section{AUTHOR CONTRIBUTIONS}

María del Mar Delgado-Serrano and Jay Mistry contributed equally to the writing and revising of the manuscript. María del Mar Delgado-Serrano coordinated the paper, but both equally contributed to organize and revise the data and ideas submitted by the other authors.
Responses to this article can be read online at: http://www.ecologyandsociety.org/issues/responses. php/8924 


\section{Acknowledgments:}

We would like to thank all our colleagues, partner institutions, and the local communities with whom we worked in the five projects, and Isabel Ruiz-Mallén for providing information on the COMBIOSERVE project. COMET-LA (282845), COBRA (282991), CiVi.net, COMBIOSERVE (282899), and EcoAdapt (283163) were funded by the Environment Program, Management of Natural Resources, DG Research and Innovation, European Commission 7th Framework.

\section{LITERATURE CITED}

Balint, P. J., and J. Mashinya. 2006. The decline of a model community-based conservation project: governance, capacity, and devolution in Mahenye, Zimbabwe. Geoforum 37:805-815. http://dx.doi.org/10.1016/i.geoforum.2005.01.011

Berardi, A., J. Mistry, C. Tschirhart, E. Bignante, O. Davis, L. Haynes, R. Benjamin, G. Albert, R. Xavier, D. Jafferally, and G. de Ville. 2015. Applying the system viability framework for crossscalar governance of nested social-ecological systems in the Guiana Shield, South America. Ecology and Society 20(3):42. http://dx.doi.org/10.5751/es-07865-200342

Berardi, A., C. Tschirhart, J. Mistry, E. Bignante, L. Haynes, G. Albert, R. Benjamin, R. Xavier, and D. Jafferally. 2013. From resilience to viability: a case study of indigenous communities of the North Rupununi, Guyana. EchoGéo 24. [online] URL: http:// echogeo.revues.org/13411 http://dx.doi.org/10.4000/echogeo.13411

Berkes, F. 2004. Rethinking community-based conservation. Conservation Biology 18:621-630. http://dx.doi.org/10.1111/ j.1523-1739.2004.00077.x

Berkes, F., and C. Folke. 1998. Linking social and ecological systems. Management practices and social mechanisms for building resilience. Cambridge University Press, Cambridge, Massachusetts, USA.

Bignante, E. 2010. The use of photo elicitation in field research: exploring Maasai representation and use of natural resources. EchoGéo 11. [online] URL: https://echogeo.revues.org/11622? lang=en http://dx.doi.org/10.4000/echogeo.11622

Bohensky, E., and T. Lynam. 2005. Evaluating responses in complex adaptive systems: insights on water management from the Southern African Millennium Ecosystem Assessment (SAfMA). Ecology and Society 10:11.

Brosius, J. P., A. L. Tsing, and C. Zerner. 1998. Representing communities: histories and politics of community-based natural resource management. Society \& Natural Resources 11:157-168. http://dx.doi.org/10.1080/08941929809381069

Callon, M., P. Lascoumes, and Y. Barthe. 2001. Agir dans un monde incertain. Essai sur la democratie technique. Seuil, Paris, France.

Caruso, E., C. Schunko, E. Corbera, I. Ruiz-Mallén, C. Vogl, G. Martin, S. Arrazola, F. Bandeira, D. Calvo-Boyero, C. CamachoBenavides, T. Mota-Cardoso, A. Chan-Dzul, E. Conde, C. del Campo-Garcí, T. Huanca, J. Larajeiras-Sampaio, S. OliverosLopez, L. Porter-Bolland, and O. Ruiz-Betancourt. 2016. Lessons for research policy and practice: the case of co-enquiry research with rural communities. Journal of Research Practice 12(1):article M1.

Colding, J., T. Elmqvist, and P. Olsson. 2003. Living with disturbance: building resilience in social-ecological systems. Pages 163-186 in F. Berkes, J. Colding, and C. Folke, editors. Navigating social-ecological systems: building resilience for complexity and change. Cambridge University Press, Cambridge, Massachusetts, USA.

Cox, M., G. Arnold, and S. Villamayor Tomá. 2010. A review of design principles for community-based natural resource management. Ecology and Society 15:28-28.

Delgado-Serrano, M. d. M., R. Escalante, and S. Basurto. $2015 b$. Is the community-based management of natural resources inherently linked to resilience? An analysis of the Santiago Comaltepec community (Mexico). Journal of Depopulation and Rural Development Studies 18:91-114.

Delgado-Serrano, M., E. Oteros-Rozas, P. Vanwildemeersch, C. Ortiz-Guerrero, S. London, and R. Escalante. 2015a. Local perceptions on social-ecological dynamics in Latin America in three community-based natural resource management systems. Ecology and Society 20(4):24. http://dx.doi.org/10.5751/ ES-07965-200424

Delgado-Serrano, M. d. M., and P. A. Ramos. 2015. Making Ostrom's framework applicable to characterise social ecological systems at the local level. International Journal of the Commons 9:808-830. http://dx.doi.org/10.18352/ijc.567

Delgado-Serrano, M. d. M., P. Vanwildemeersch, S. London, C. E. Ortiz-Guerrero, R. Escalante Semerena, and M. Rojas. 2016. Adapting prospective structural analysis to strengthen sustainable management and capacity building in communitybased natural resource management contexts. Ecology and Society 21(2):36. http://dx.doi.org/10.5751/es-08505-210236

Devisscher, T., R. Vignola, M. Coll Besa, R. Cronenbold, N. Pacheco, R. Schillinger, V. Canedi, C. Sandoval, D. Gonzalez, and G. Leclerc. 2016. Understanding the socio-institutional context to support adaptation for future water security in forest landscapes. Ecology and Society 21(4):48. https://doi.org/10.5751/ ES-08988-210448

Dietz, T., E. Ostrom, and P. C. Stern. 2003. The struggle to govern the commons. Science 302:1907-1912. http://dx.doi.org/10.1126/ science. 1091015

Dressler, W., B. Bücher, M. Schoon, D. Brockington, T. Hayes, C. A. Kull, J. McCarthy, and K. Shrestha. 2010. From hope to crisis and back again? A critical history of the global CBNRM narrative. Environmental Conservation 37:5-15. http://dx.doi. org/10.1017/S0376892910000044

Escalante, R. I., S. Basurto, S. I. Brugger, Y. Lara, F. Chapela, and I. Hernádez. 2012. Stakeholders' vision on the social-ecological system situation in Mexico. A case study. COMET-LA Working paper. [online] URL: http://www.comet-la.eu/index.php/en/ publications.html

Fabricius, C., and S. Collins. 2007. Community-based natural resource management: governing the commons. Water Policy 9:83-97. http://dx.doi.org/10.2166/wp.2007.132 
Fallot, A., and J.F. Le Coq. 2014. Sistemas socio-ecolóicos: un enfoque integral para comprender las interacciones de los seres humanos y la naturaleza. Experiencia de modelació participativa en tres territorios de Améica Latina. REDESMA 14:8.

Farah, M. A., E. Garrido, D. L. Maya, C. Ortiz, and P. Ramos. 2012. Stakeholder vision on social-ecological system situation in Colombia case study. COMET-LA Publications. [online] URL: http://www.comet-la.eu/index.php/en/publications.html

Flannery, T. 2007. The weather makers: how man is changing the climate and what it means for life on Earth. Grove/Atlantic, Inc., New York, USA.

Food and Agriculture Organization of the United Nations (FAO). 2015. Global forest resources assessment 2015: desk reference. Food and Agriculture Organization of the United Nations. [online] URL: http://www.fao.org/3/a-i4808e.pdf

Foucault, M. 2007. The politics of truth. Second edition. Semiotext(e)/Foreign Agents Series, Semiotext Publisher, Los Angeles, California, USA.

Hayes, T. M. 2007. Does tenure matter? A comparative analysis of agricultural expansion in the Mosquitia Forest Corridor. Human Ecology 35:733-747. http://dx.doi.org/10.1007/s10745-007-9117-6

Intergovernmental Panel on Climate Change (IPCC). 2014. Climate change 2014: impacts, adaptation, and vulnerability. Part A: global and sectoral aspects. Contribution of Working Group II to the Fifth Assessment Report of the Intergovernmental Panel on Climate Change. C. B. Field, V. R. Barros, D. J. Dokken, K. J. Mach, M. D. Mastrandrea, T. E. Bilir, M. Chatterjee, K. L. Ebi, Y. O. Estrada, R. C. Genova, B. Girma, E. S. Kissel, A. N. Levy, S. MacCracken, P. R. Mastrandrea, and L. L. White, editors. Intergovernmental Panel on Climate Change, Cambridge, United Kingdom and New York, New York, USA.

Kamran, M. A., and G. P. Shivakoti. 2009. Design principles and robustness of spate community managed irrigation systems in the Punjab, Pakistan. Digital Library of the Commons. Indiana University, Bloomington, Inidiana, USA. [online] URL: https:// www.researchgate.net/publication/42760989_Design_Principles and Robustness of Spate Community Managed Irrigation Systems in the Punjab Pakistan

Kellert, S. R., J. N. Mehta, S. A. Ebbin, and L. L. Lichtenfeld. 2000. Community natural resource management: promise, rhetoric, and reality. Society \& Natural Resources 13(8):705-715. http://dx.doi.org/10.1080/089419200750035575

Kinzig, A. P., P. R. Ehrlich, L. J. Alston, K. Arrow, S. Barrett, T. G. Buchman, G. C. Daily, B. Levin, S. Levin, and M. Oppenheimer. 2013. Social norms and global environmental challenges: the complex interaction of behaviors, values, and policy. BioScience 63:164-175. http://dx.doi.org/10.1525/bio.2013.63.3.5

Klooster, D. 2000. Institutional choice, community, and struggle: a case study of forest co-management in Mexico. World Development 28:1-20. http://dx.doi.org/10.1016/S0305-750X(99) 00108-4

Latour, B. 2001. Le méier de chercheur: Regard d'n anthropologue. INRA Editions, Quae, Versaille, France.
Leclerc, G. 2014. EcoAdapt Working Paper Series $N^{\circ} 2$ : iModeler manual: a quick guide for fuzzy cognitive modelling. [online] URL: https://hal.archives-ouvertes.fr/hal-01104035

London, S., M. Recalde, M. Rojas, M. Zilio, G. M. E. Perillo, M. L. Bustos, M. C. Piccolo, C. Rodriguez, G. Fidalgo, J. C. Pascale, L. Berninsone, M. A. Huamantinco Cisneros, M. d. C. Vaquero, and P. Bordino. 2012. Stakeholder vision on social-ecological system situation in Argentina case study. COMET-LA Working Paper. [online] URL: http://www.comet-la.eu/index.php/en/ publications.html

Mistry, J., and A. Berardi. 2012. The challenges and opportunities of participatory video in geographical research: a case study exploring collaboration with indigenous communities in the North Rupununi, Guyana. Area 44:110-116. http://dx.doi. org/10.1111/j.1475-4762.2011.01064.x

Mistry, J., and A. Berardi. 2016. Bridging indigenous and scientific knowledge. Science 352(6291):1274-1275. http://dx.doi. org/10.1126/science.aaf1160

Mistry, J., A. Berardi, E. Bignante, and C. Tschirhart. 2015. Between a rock and a hard place: ethical dilemmas of local community facilitators doing participatory research projects Geoforum 61:27-35. http://dx.doi.org/10.1016/j.geoforum.2015.02.010

Mistry, J., A. Berardi, C. Tschirhart, E. Bignante, L. Haynes, R. Benjamin, G. Albert, R. Xavier, D. Jafferally, and G. de Ville. 2014a. Indigenous identity and environmental governance in Guyana, South America. Cultural Geographies 22(4):689-712. http://dx.doi.org/10.1177/1474474014560998

Mistry, J., A. Berardi, C. Tschirhart, E. Bignante, L. Haynes, R. Benjamin, G. Albert, R. Xavier, B. Robertson, O. Davis, D. Jafferally, and G. de Ville. 2016. Community owned solutions: identifying local best practices for social-ecological sustainability. Ecology and Society 21(2):42. http://dx.doi.org/10.5751/ es-08496-210242

Mistry, J., C. Tschirhart, C. Verwer, R. Glastra, O. Davis, D. Jafferally, L. Haynes, R. Benjamin, G. Albert, R. Xavier, I. Bovolo, and A. Berardi. 2014b. Our common future? Cross-scalar scenario analysis for social-ecological sustainability of the Guiana Shield, South America. Environmental Science \& Policy 44:126-148. http://dx.doi.org/10.1016/j.envsci.2014.05.007

Mittermeier, R. A., P. Robles-Gil, and C. G. Mittermeier. 1997. Megadiversity: Earth's biologically wealthiest nations. CEMEX/ Agrupacion Sierra Madre, Mexico City, Mexico.

Nolte, C., A. Agrawal, K. M. Silviu, and B. S. Soares-Filho. 2013. Governance regime and location influence avoided deforestation success of protected areas in the Brazilian Amazon. Proceedings of the National Academy of Sciences of the United States of America 110(13):4956-4961. http://dx.doi.org/10.1073/pnas.1214786110

Olson, D. M., E. Dinerstein, E. D. Wikramanayake, N. D. Burgess, G. V. Powell, E. C. Underwood, J. A. D'amico, I. Itoua, H. E. Strand, J. C. Morrison, C. J. Loucks, T. F. Allnutt, T. H. Ricketts, Y. Kura, J. F. Lamoreux, W. W. Wettengel, P. Hedao, and K. K. Kassem. 2001. Terrestrial ecoregions of the world: a new map of life on Earth. A new global map of terrestrial ecoregions provides 
an innovative tool for conserving biodiversity. BioScience 51 (11):933-938. http://dx.doi.org/10.1641/0006-3568(2001)051[0933: teotwa]2.0.co:2

Ostrom, E. 1990. Governing the commons: the evolution of institutions for collective action. Cambridge University Press, Cambridge, Massachusetts, USA.

Prins, K., A. á Cattá, N. Azcarrúz, A. Real, L. Villugron, G. Leclerc, R. Vignola, M. Morales, and B. Louman. 2015. Creating and sharing new knowledge through joint learning on water governance and climate change adaptation in three Latin American model forests: the ecoadapt case. IUFRO Occasional Paper 30.

Ruiz-Mallén, I., E. Corbera, D. Calvo-Boyero, and V. ReyesGarcia. 2015b. Participatory scenarios to explore local adaptation to global change in biosphere reserves: experiences from Bolivia and Mexico. Environmental Science \& Policy 54:398-408. http:// dx.doi.org/10.1016/j.envsci.2015.07.027

Ruiz-Mallén, I., C. Schunko, E. Corbera, M. Rös, and V. ReyesGarcia. 2015a. Meanings, drivers, and motivations for community-based conservation in Latin America. Ecology and Society 20(3):33.

Sattler, C., and B. Schröer. 2015. Living by strict rules: comanagement as a way to prevent eviction from a conservation area - the case of the Marujácommunity in Brazil. Solutions 6 (3):58-66.

Sattler, C., B. Schröer, C. JericóDaminello, K. Sessin-Dilascio, C. Meyer, B. Matzdorf, L. Wortmann, P. de Almeida Sinisgalli, A. Meyer, and G. Giersch. 2015. Understanding governance structures in community management of ecosystems and natural resources: the Marujá case study in Brazil. Ecosystem Services 16:182-191. http://dx.doi.org/10.1016/j.ecoser.2015.10.015

Scales, I. R. 2012. Lost in translation: conflicting views of deforestation, land use and identity in western Madagascar. Geographical Journal 178:67-79. http://dx.doi.org/10.1111/ j.1475-4959.2011.00432.x

Schiffer, E., and J. Hauck. 2010. Net-map: collecting social network data and facilitating network learning through participatory influence network mapping. Field Methods 22:231249. http://dx.doi.org/10.1177/1525822X10374798

Shackleton, C. M., T. J. Willis, K. Brown, and N. V. C. Polunin. 2010. Reflecting on the next generation of models for communitybased natural resources management. Environmental Conservation 37:1-4. http://dx.doi.org/10.1017/S0376892910000366

Suich, H. 2013. The effectiveness of economic incentives for sustaining community based natural resource management. Land Use Policy 31:441-449. http://dx.doi.org/10.1016/j.landusepol.2012.08.008

Tschirhart, C., J. Mistry, A. Berardi, E. Bignante, M. Simpson, L. Haynes, R. Benjamin, G. Albert, R. Xavier, B. Robertson, O. Davis, C. Verwer, G. de Ville, and D. Jafferally. 2016. Learning from one another: evaluating the impact of horizontal knowledge exchange for environmental management and governance. Ecology and Society 21(2):41. http://dx.doi.org/10.5751/ es-08495-210241
United Nations Economic Commission for Latin America and the Caribbean (UNECLAC). 2014. Handbook for disaster assessment. United Nations Economic Commission for Latin America and the Caribbean, Santiago, Chile.

United Nations Environment Programme (UNEP). 2016. GEO-6 regional assessment for Latin America and the Caribbean. United Nations Environment Programme, Nairobi, Kenya.

Vergara-Asenjo, G., and C. Potvin. 2014. Forest protection and tenure status: the key role of indigenous peoples and protected areas in Panama. Global Environmental Change 28:205-215. http://dx.doi.org/10.1016/j.gloenvcha.2014.07.002

Vignola, R., J. Gonzales, and M. Morales. 2014. Working paper on social dynamics during adaptation planning. EcoAdapt Working Paper Series $N^{\circ}$ 17: adaptation to climate change for local development. [online] URL: https://goo.gl/1XLCm2

Walker, W., A. Baccini, S. Schwartman, S. Ríos, M. A. OliveiraMiranda, C. Augusto, M. R. Ruiz, C. S Arrasco, B. Ricardo, R. Smith, C. Meyer, J. C. Jintiach, and E. V. Campos. 2015. Forest carbon in Amazonia: the unrecognized contribution of indigenous territories and protected natural areas. Carbon Management 5(5-6):479-485. http://dx.doi.org/10.1080/175830$\underline{04.2014 .990680}$

Waylen, K. A., J. Martin-Ortega, K. L. Blackstock, I. Brown, B. E. Avendañ Uribe, S. Basurto Hernádez, M. B. Bertoni, M. L. Bustos, A. X. Cruz Bayer, R. I. Escalante Semerena, M. A. Farah Quijano, F. Ferrelli, G. L. Fidalgo, I. Hernádez Lóez, M. A. Huamantinco Cisneros, S. London, D. L. Maya Véez, N. OcampoDíz, C. E. Ortiz-Guerrero, J. C. Pascale, G. M. E. Perillo, M. C. Piccolo, L. N. Pinzó Martíez, M. L. Rojas, F. Scordo, V. Vitale, and M. I. Zilio. 2015. Can scenario-planning support communitybased natural resource management? Experiences from three countries in Latin America. Ecology and Society 20(4):28. http:// dx.doi.org/10.5751/es-07926-200428

Western, D., and R. M. Wright. 1994. Natural connections: perspectives in community based conservation. Island Press, Washington, D.C., USA.

White, A. T., C. A. Courtney, and A. Salamanca. 2002. Experience with marine protected area planning and management in the Philippines. Coastal Management 30:1-26. http://dx.doi. org/10.1080/08920750252692599

Znajda, S. K. 2014. What is 'successful development' in conservation and development projects? Insights from two Nicaraguan case studies. Conservation \& Society 12(3):318-328. http://dx.doi.org/10.4103/0972-4923.145157 